\title{
Elülső keresztszalag pótlására felhasználható humán allograftok biomechanikai vizsgálata
}

\author{
DR. HANGODY GYÖRGY MÁRK, DR. PAP KÁROLY, DR. SZEBÉNYI GÁBOR, \\ DR. KISS RITA, DR. HANGODY LÁSZLÓ
}

\section{ÖSSZEFOGLALÁS}

Az elülső keresztszalag pótlás során visszaállítjuk a térdízület nyílirányú és rotációs stabilitását, csökkentve ezzel az idő előtti porckopás esélyét. Az LCA rekonstrukciós mútét egyik legmeghatározóbb eleme az optimális graftválasztás. A kutatási projektünk célja volt értékelni az LCA pótlásra felhasználható humán allograftok szilárdságtani tulajdonságait, továbbá azoknak változásait a fagyasztás, illetve a gamma besugárzás hatására. A mért paraméterek alapján kívántuk meghatározni a legjobb graft jelölteket és a tartósítás optimális feltételeit. Munkánk két fő részből állt. Vizsgálataink első szakaszában 8 db humán kadáver 40 íngraftjával teszteltünk 6-féle befogási technikát, ezáltal teremtve meg a reprodukálható szakításos mérések feltételeit. Csak az általunk - fagyasztással kombinált - módosított Shi-féle befogóval értünk el minden esetben szakítási fenomén, valamint a mért szakítási erők értékei is korreláltak a nemzetközi irodalomban leírtakkal. Kutatásunk második részében 24 órán belül elhalálozott, tumor- és fertőzésmentes 30 kadáverből 300 íngraftot harvesztáltunk és ezek segítségével vizsgáltuk az íngraftok szilárdságtani tulajdonságainak változásait a különböző dózisú gammasugárzás hatására. A (-80) Celsius fokra fagyasztott oltványok szakítószilárdságát INSTRON 8872 típusú szakítógéppel és az általunk fejlesztett speciális rögzítési technika segítségével vizsgáltuk. A graftokat statikus és dinamikus szilárdságtani teszteknek vetettük alá. Mintáinkat 3 csoportba osztottuk: fagyasztott, nem besugarazott, kis dózisú ( 21 kGy) és nagy dózisú (42 kGy) gamma-sugárzással kezelt graftok. Négy biomechanikai paraméter alapján próbáltunk választ keresni arra, hogy a különböző típusú ínmintáink szilárdságtani tulajdonságai miképp változnak meg a baktericid és virucid dózisú sugárzás hatására. Megállapítottuk, hogy a peroneus longus, tibialis anterior inak rendelkeznek a legjobb biomechanikai tulajdonságokkal. Az Achilles és quadriceps íngraftok biomechanikai tulajdonságai károsodtak leginkább a gamma-besugárzás hatására.

\section{Kulcsszavak: $\quad$ Allograftok; Anyagvizsgálat; Biomechanika; Elülsö keresztszalag; Gammasugárzás; Íntranszplantáció; Szakitószilárdság;}

Gy. M. Hangody, K. Pap, G. Szebényi, R. Kiss, L. Hangody: Biomechanical analysis of human allografts for $A C L$ reconstruction

During the anterior cruciate ligament reconstruction the saggital stability of the knee joint is restored, which reduces the chances of premature osteoarthritis. One of the most significant elements of $A C L$ reconstruction surgery is the optimal graftchoice. The research project is aimed to evaluate the strength properties of human allografts that can be used for $\mathrm{ACL}$ reconstruction, and the possible changes in their strenghth caused by freezing and gamma irradiation. We wanted to determine the optimum conditions and graft preservation technique. Our work consisted of two main parts. In the first stage the conditions for the reproducible tensional measurements were created, in the second phase the biomechanical properties of the tendografts were examined and how they change after bactericidal and virucidal doses of gamma radiation. In the first part of our study we tested 40 tendografts with six different types of fixation devices. Only the Shi's modified-frozen clamp was suitable to achieve the rupture phenomena in each case, and the measured tensile forces correlated with values described in the international literature. In the second phase of our research we harvested 300 tendografts from 30 tumor and infection-free human cadavers died within 24 hours. Following harvesting, the grafts were cooled down to $(-80)$ Celsius degrees and stored. The grafts were tested on an Instron 8872 loading machine with special fixing technique developed 
by our research group. The grafts were tested statically and dynamically. Our samples were divided into 3 groups: frozen, non-irradiated, low dose ( $21 \mathrm{kGy}$ ), and high dose (42 kGy) of gamma-irradiated grafts. Four biomechanical parameters were measured, and compared statistically to evaluate the biomechanical properties of the different types of tendografts and the changes caused by bactericidal and virucidal doses of gamma irradiation. Our studies showed that the peroneus longus and tibialis anterior grafts have better biomechanical properties, than the others. The Achilles and quadriceps specimens' biomechanical properties were damaged mostly by gamma-irradiation.

Keywords: $\quad$ Allografts - Physiology; Anterior cruciate ligament - Physiology; Biomechanical phenomena; Gamma rays; Materials Testing - Methods; Tendons - Transplantation; Tensile Strength;

\section{BEVEZETÉS}

Az utóbbi közel száz évben az elülső keresztszalag pótlása hatalmas fejlődésen ment keresztül a ma jellemző jó eredmények eléréséig, olyannyira, hogy mára az egyik leggyakrabban végzett operatív beavatkozás lett a mozgásszervi sebészetben $(2,5)$. A XXI. század elején kezdett egyre nagyobb szerepe lenni az allograftokkal végzett szalagpótlásoknak, különös tekintettel az elülső keresztszalag pótlására. Az évezred elejére az allografttal végzett LCA-pótlás incidenciája 2\%-ról (1986-1996) 14\%-ra (1996-2001) növekedett az USA-ban, ami igencsak figyelemre méltó változás (12).

A keresztszalagok alapvetően nyílirányban stabilizálják az ízületet, és tengelyül szolgálnak a rotációs mozgásokhoz is. Szalaghiány esetén a csúszó és gördülő mozgások viszonylagos szétesése miatt kialakuló instabilitás révén fokozott porckopási hajlam alakul ki. A legtöbb mozgásszervi sebész egyetért abban, hogy az elülső keresztszalag szakadása „a térd végének a kezdete" (6).

A mai szemlélet szerint LCA-szakadás esetén a szalagot a sérülést követő néhány hét múlva pótoljuk, legtöbbször autológ grafttal (halasztott pótlás). A pótlás során a beültetett szalagstruktúra beereződik, és primer stabilitást is adva vázként („,scaffold”-ként) szolgál a szalag átépülését reprezentáló „,ligamentizációs folyamatban". Ennek során az oltvány a megfelelően adagolt terheléshez adaptálódva fokozatosan átépül, amelynek során kollagén rostokkal telítődik, s mintegy egy éves folyamat során elnyeri végleges új szerkezetét.

$\mathrm{Az}$ Amerikai Egyesült Államokban egyre népszerúbbek az ínallograftok, azonban az ebből készült úgynevezett medical device-ok használatát Európában az uniós szabályozások még nem minden országban engedélyezik, de a korlátozások ellenére egyre nagyobb az irántuk való érdeklődés. Az allograftok használatával kiküszöbölhető a donorterületi morbiditás, nem gyengíti a flexor és extensor apparátust, csökkenti a mútéti időt, kisebb metszés szükséges hozzá, kevesebb a posztoperativ fájdalom, jobb kozmetikai eredményt ad, csökkenti a mútét utáni arthrofibrosis kialakulását és tetszőleges méretű graft választható a sérült keresztszalag pótlására. Emellett kifejezetten ajánlottak revíziós mútétek elvégzéséhez és összetett térdszalag-sérülések korrekciójára $(17,18,22,28)$. Hátrányai azonban, hogy mivel „idegen szövetek”, így betegségeket közvetíthetnek. További negatívumként említhető a graftok nyerésének és tárolásának nehézsége.

Az allograftokat használhatjuk akár friss-fagyasztott - nem sterilizált - akár cryopreservált, akár a beültetés előtt különböző sterilizálási metódusokon átesett formában. Napjainkban a legnépszerübbnek az alacsony dózisú ( $\leq 25 \mathrm{kGy}$ ) $\gamma$-besugárzás mondható az USA-ban és Európa bizonyos részein is az $\mathrm{LCA}$-allograftok sterilizálására. Ez a metódus eliminálja a baktériumokat, gombákat és a vírusok egy részét, de nem az összes patogént (3). Abban a legtöbben egyetértenek, hogy terminális dózisú $y$-besugárzás lenne szükséges annak érdekében, hogy a beültetésre szolgáló allograftnál 10-6 szintű SAL-t (sterility assurance level) - biztonsági szintet - érhessünk el, amely ekvivalens az orvosi eszközök implantálási követelményeivel.

Kutatásunk során humán íngraftok szakításos vizsgálatait végeztük, amelyek során a biomechanikai tulajdonságaikat, illetve azoknak a fizikai és kémiai ágensek behatására kialakuló változásait mértük. Munkánk két fő részből állt. Vizsgálataink első fázisában a későbbi mérésekhez alkalmas befogófej 
kialakítása volt a célunk. A második fázis során arra kerestük a választ, hogy az előkezelési eljárások, amelyekben a graftok részesültek (pl. radiocryoprotectans oldat, fagyasztás), továbbá a gammasugárzás, illetve annak dózisa miképpen befolyásolja a graftok szilárdságtani tulajdonságait.

\section{ANYAG ÉS MÓDSZER}

a) Szakításos vizsgálatokhoz alkalmas befogófejek tesztelése, az alkalmas rögzítési metódus megtalálása

40 íngraftot gyújtöttünk 8 humán kadáverből (tumor- és fertőzésmentesek). Eltávolításra kerültek a csont-patellaín-csont graftok (BTB-/BPTB-graftok), a semitendinosus és gracilis ínpárosok (ST/G), a quadriceps inak, az Achilles- és a peroneus longus inak a donorok egyik alsó végtagjából. Az eltávolítás a megfelelő sebészi protokollok alapján történt, a halál beálltához képest 24 órán belül. $\mathrm{Az}$ oltványokat 6-féle fixációs metódussal/ eszközzel teszteltük. Ezek a következők voltak: sebészi fonal (Premicron 3 típusú), drótháló (Maedchenfaenger típusú), Zwick Z020-as típusú szakítógéphez tartozó általános befogófej, cementköpenyes fixáció, Shi-féle befogó (27), módosított fagyasztással kombinált Shiféle befogófej INSTRON típusú szakítógéphez. Méréseinket INSTRON 8872 típusú, komputervezérelt, szervohidraulikus szakítógéppel végeztük. Minden egyes graft keresztmetszetét is lemértük, hogy a kapott biomechanikai adatokat megfelelőképpen tudjuk értékelni. Az adataink statisztikai értékeléséhez kétmintás T-próbát végeztünk.

\section{b) Fagyasztott és fagyasztva besugarazott ínminták statikus és dinamikus terhelése}

Vizsgálatunk második fázisában 30 tumorés fertőzésmentes humán kadáverből 300 graftot gyűjtöttünk, a halál beálltához képest 24 órán belül. Minden egyes donorból alsó végtagonként 5-5 íngraftot távolítottunk el: Achilles, quadriceps, semitendinosus+gracilis (ST+G vagy $S T / G$ vagy $S T G)$, tibialis anterior (TA) és peroneus longus ( $\mathrm{PL}$ ) inakat. Az eltávolítást követően az oltványokat radiocryoprotectans oldatba helyeztük és 40 Celsius fok hőmérsékleten 4 órán át tároltuk őket - folyamatos mozgatás mellett - majd 24 órán keresztül 4 Celsius fok hőmérsékleten, végül $(-80)$ Celsius fok hőmérsékletre fagyasztottunk, így érve el az ideiglenes tárolás feltételeit.

Az ínmintákat 3 csoportba osztottuk. Az A csoport 100 fagyasztott ínmintát tartalmazott (kontrollcsoport). A B csoportban is 100 graftot teszteltünk, amelyeket 21 kGy céldózisú (baktericid dózis) gammasugárzással kezeltünk. A C csoportba pedig szintén 100 db 42 kGy céldózisú (virucid dózis) gammabesugárzással kezelt ínminta került későbbi vizsgálatok céljából. A szakításos mérésekhez a graftokat felolvasztottuk, míg el nem érték a szobahőmérsékletet. Tesztelés előtt a mintáknál a keresztmetszetet és a befogófejek közti távolságot is lemértük a mérési adatok összehasonlíthatósága és értékelhetősége miatt. A graftok végeit a fagyasztott befogófejekbe fixáltuk, és a szakításos vizsgálatokat megelőzően 30 másodpercen át 50 N-nal előfeszítettük az ínmintáinkat. Ezt követően 50-200 N közötti előterheléssel, 2 Herz frekvenciával 1000 ciklus alatt dinamikusan terheltük az inakat, majd a nyújtási erőt folyamatosan növelve szakítottuk őket. A szakításos vizsgálatokhoz ezen esetekben is INSTRON 8872 típusú szakítógépet használtunk.

$\mathrm{Az}$ egyes csoportok eloszlását ShapiroWilks- és Kolmogorov-Smirnov-teszttel végeztük. Az adatainkat mediánként reprezentáltuk a hozzá tartozó interkvartilis tartománnyal (25\% percentilis - 75\% percentilis). A csoportonkénti összehasonlításhoz KruskalWallis-tesztet használtunk. Az összes analízisnél a $p \leq 0,05$ értéket tekintettük statisztikailag szignifikánsnak.

\section{EREDMÉNYEK}

a) A szakításos vizsgálatokhoz használt befogófejekkel elért eredményeink

Az első esetben az íngraftok fixálása hasonló metódussal történt, mint az elülső keresztszalag sebészi pótlása során. A ST+G inakat négyrétegúre hajtottuk, és a szabad végeiket Premicron 3 típusú fonallal öltöttük össze, ellenkező végeiken pedig a fonalat aláhurkoltuk. Az általunk mért szakítási erők átlaga (381ะ26 N) megfelelt az irodalomban leírtaknak.

A fonalas rögzítés kudarca után a Zwick Z020 típusú szakítógép általános befogófejét 
teszteltük. Sajnos itt sem értük el a kellő eredményt $(527 \pm 45 \mathrm{~N})$. Ennek oka, hogy a graftok befogása során az izomrostokban kisebb sérülések léphettek fel, és ez több esetben mérési hibát is okozott. Előfordult, hogy az ín kicsúszott a befogófej lapjai közül, továbbá ez a szerkezet a BPTB-graftok csontos végeit nem volt képes rögzíteni.

Méréseink 3. szakaszában a dróthálós rögzítési módszert (ún. Maedchenfaengert) teszteltük. Nagy hátránya volt, hogy csak a csontos végekkel rendelkező BPTB-graftok rögzítési megoldásaként jöhetett szóba. Az eredmények már biztatóbbak voltak $(751 \pm 21 \mathrm{~N})$, de még nem érték el az általunk kívántakat.

A negyedik esetben a graftok végének cementes rögzítésére tettünk kísérletet, de az izomrostok és a cement közötti súrlódási együttható alacsony volta miatt az ínvégek relatíve könnyen kicsúsztak a cementköpenyből (253 \pm 19 N). Továbbá némely esetben a cementköpeny sérülést szenvedett el a befogófej lapjai közé való rögzítés során.

Ezután a Shi-féle befogót használtuk (27) (1. ábra). A vékonyabb minták - peroneus, semitendinosus - a legtöbb esetben kicsúsztak a befogófejek lapjai közül. Az átlagos szakítási erő $997 \pm 416 \mathrm{~N}$ volt, de ez a többségében nem hozta létre a szakítási fenomént.

Végül a Shi-féle befogót fagyasztással kombináltuk, amelyet módosított ínbefogónak neveztünk el (2. ábra). A szakításhoz szükséges erő (2198 \pm 773 N) és az ín tényleges szakadása megmutatta, hogy sikerült megtalálnunk az inak szilárdságtani vizsgálatához használható befogóeszközt. Az erő-megnyúlás görbéje pedig karakterisztikus volt (3. ábra). A legnagyobb szakítási erő, amelyet elértünk 3298,5 N volt.

$A z$ 5. és a 6 . rögzítési metódussal elért eredményeinket kétmintás T-próbával hasonlítottuk össze, amely szignifikáns különbséget talált a két csoport között $(p=0,01152)$. Az öszszes graft elszakadt, kivéve a BPTB-graftokat, amelyeknél a maximális feszültséget átlagosan csak $1030 \mathrm{~N}$-ig lehetett növelni. A csontpatellaín-csont graftok mind a Shi-féle, mind a fagyasztással kombinált befogókból egyaránt kicsúsztak. Fontos megemlíteni, hogy ezen graftok átlagos hossza mindössze $6,375 \mathrm{~cm}$ volt, míg a többi mintáé 9,25-12,125 cm közötti értékeket vett fel.
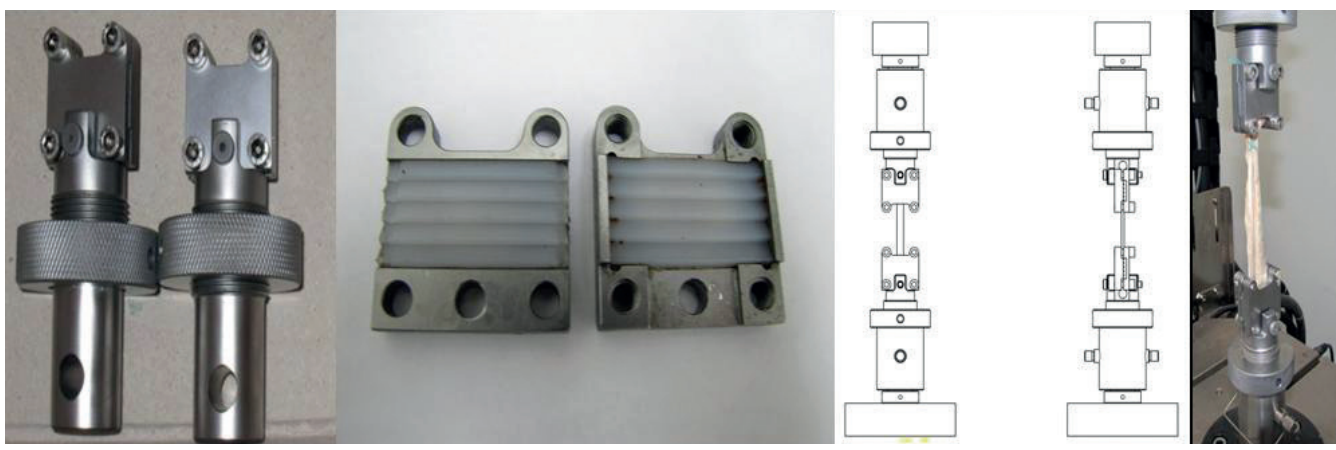

1. ábra

Shi-féle befogó. Balról-jobbra haladva láthatóak: a két befogóvég, a befogófej egymással szembenéző lapjai, a befogó sematikus rajza szemböl/oldalnézetböl, végül a befogó ínszakítás közben 

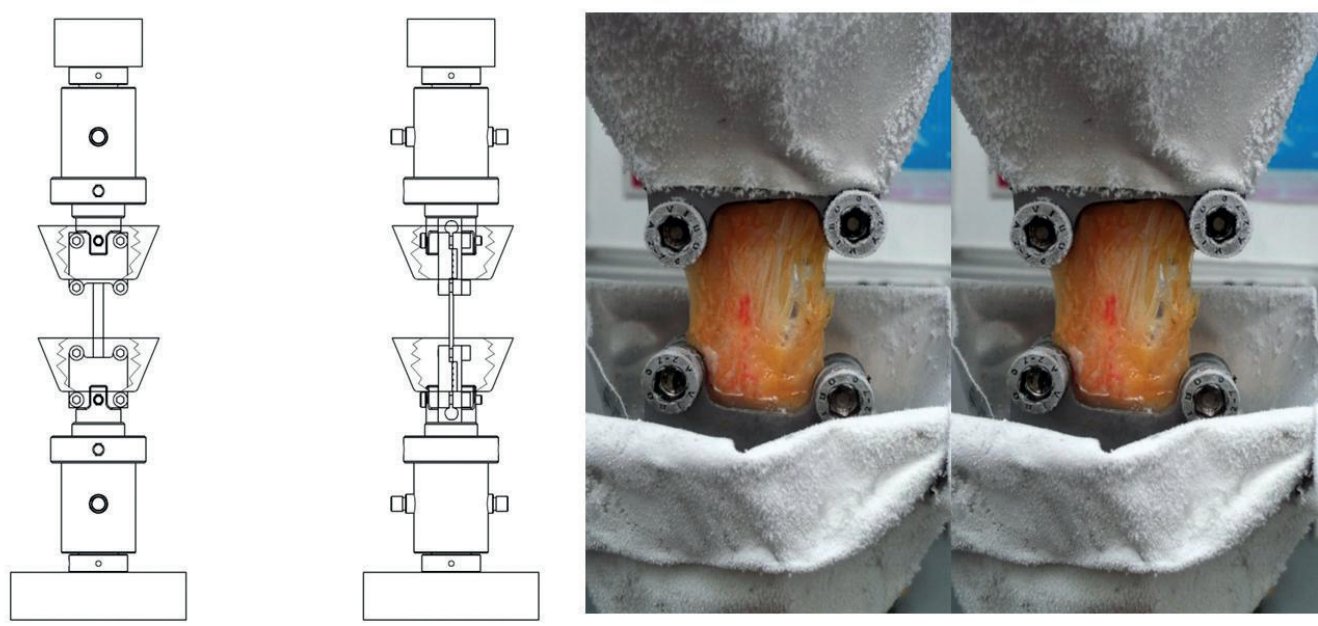

\section{2. ábra}

Fagyasztással kombinált módositott Shi-féle befogó sematikus rajza szemböl és oldalnézetböl, illetve müködés közben - létrehozva a szakitási fenomént. Mindkét ábrán látható a befogófejeket körbeölelö kádak, amelyekbe a mérések alkalmával szárazjeget helyeztünk a jobb rögzítés elérése miatt
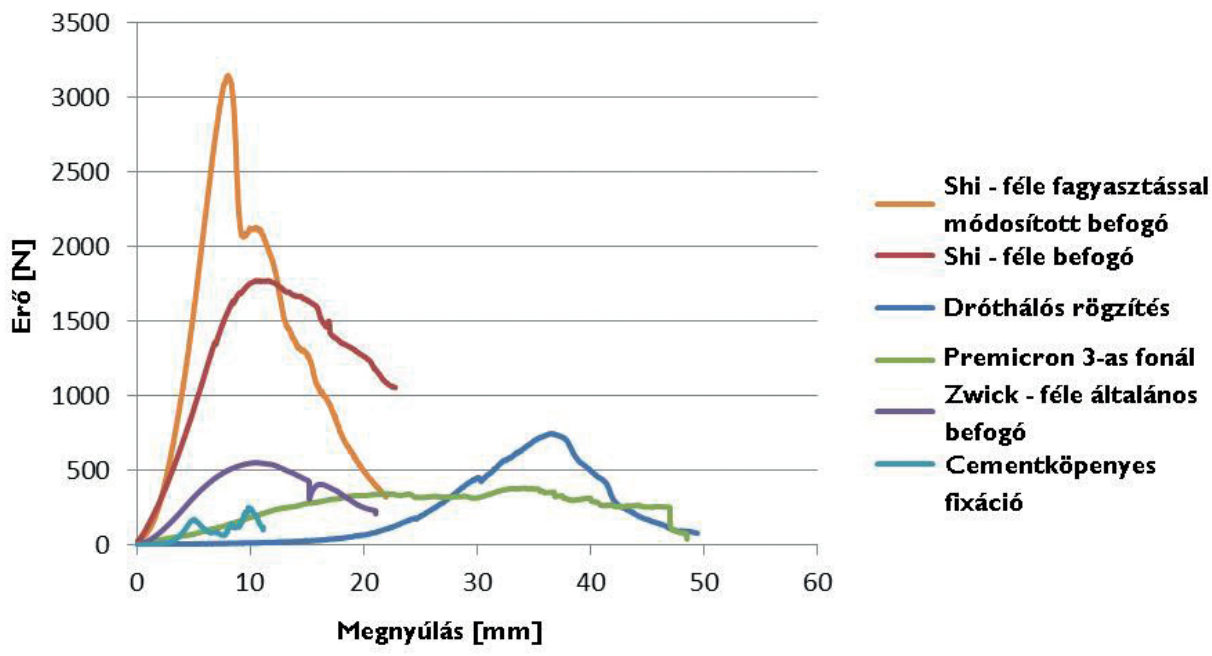

3. ábra

Szakitási görbék különbözö rögzítési metódusok használata során 


\section{b) Fagyasztott és fagyasztva besugara- zott ínminták statikus és dinamikus terhelése során elért eredményeink}

Az egyes specimenek biomechanikai öszszehasonlítására 4 paramétert használtunk: rugalmassági (Young) modulus, szakítási erő $\left(F_{\text {max }}\right)$, nyúlás maximális feszültségnél, szakadási nyúlás. A rugalmassági („Young”) modulus (MPa: $\mathrm{N} / \mathrm{mm}^{2}$ ) az egységnyi keresztmetszetre eső rugalmasságot reprezentálja. Maximális feszültség (MPa: $\mathrm{N} / \mathrm{mm}^{2}$ ): az inak szakadás előtti $\mathrm{mm}^{2}$-re vonatkoztatott erővel szembeni ellenállása. Nyúlás maximális feszültségnél $(\mathrm{mm} / \mathrm{mm})$ : az eredeti hossz és megnyúlt hossz hányadosa. Szakadási nyúlás $(\mathrm{mm} / \mathrm{mm})$ : az eredeti hossz és a szakadás pillanatában mért ínhossz hányadosa.

Az A csoportban a Young-modulus vonatkozásában összehasonlítva az ínmintáinkat megállapítható volt, hogy az Achilles-íngraftokkal szignifikánsan gyengébb értékeket értünk el, mint a TA-val $(p=0,0036)$. A szakítási erők tekintetében a vizsgált graftok között nem mutatkozott lényegi különbség, azonban az STG-inak alulteljesítettek a többi négyhez képest. Az Achilles-inak nyúlása maximális feszültségnél szignifikánsan nagyobb volt, mint az ST- $(p=0,0016)$, TA$(p=0,042)$ és a quadriceps íngraftoké $(p=0,002)$. A szakadási nyúlás esetén pedig azt lehetett látni, hogy az Achilles-ín az ST $(p=0,0103)$ és a TA-graftokkal $(p=0,0199)$ összehasonlítva is szignifikánsan nagyobb értékeket ért el (4-7. ábra).

A $B$ csoportban is elsőként az inak rugalmassági modulusát vizsgáltuk; az Achilles-ín szignifikánsan gyengébben teljesített mind a quadriceps $(p=0,0042)$, mind a PL- $(p=0,028)$, mind a TA- $(p=0,0001)$ inakkal való összehasonlítás során. A szakítási erő paramétereket értékelve láthattuk, hogy a STG-graftok szignifikánsan gyengébben teljesítettek az Achilles $(p=0,002)$ és a quadriceps $(p=0,01)$ mintákkal történt egybevetés alkalmával. Az Achilles-ín, a quadriceps és a tibialis anterior ínminták között pedig nem volt lényegi különbség. Az Achilles-inak a nyúlás maximális feszültségnél értékeit vizsgálva is szignifikánsan alulteljesítettek a quadriceps $(p=0,017)$ és az STG$(p=0,000056)$ graftokhoz képest. Az Achilles-ín szakadási nyúlása szignifikánsan nagyobb volt, mint az STG $(p=0,000029), P L-(p=0.000032)$, és TA- $(p=0.00044)$ inaké; hasonlóképpen a quadriceps ín is szignifikánsan alulmaradt az STG- $(p=0,0215)$ és TA- $(p=0,0232)$ íngraftokkal összehasonlítva (4-7. ábra).

A C csoportban a Young-modulusokat összehasonlítva megállapíthattuk, hogy az Achilles-ín szignifikánsan alulteljesített a PL- $(p=0,000042)$ és a TA- $(p=0,00142)$ graftokhoz képest. Továbbá a quadriceps inak a TA-okhoz képest $(p=0,0037)$ és az STG-graftok ugyancsak a TA-inakkal összehasonlítva ( $p=0,0432)$ szignifikánsan gyengébb rugalmassági mutatókkal rendelkeztek. Az Achilles-ín jobb eredményeket ért el a szakítási erő vonatkozásában a PL- $(p=0,0016)$ és az STG$(p=0,0066)$ graftokkal való összehasonlításkor. A quadriceps íngraftok is jobb eredményeket mutattak, mint a PL- $(p=0,0018)$ és a STG-inak $(p=0,0019)$. A TA hasonló eredményeket ért el, mint az Achilles-ín és a quadriceps. A nyúlás maximális feszültségnél szignifikánsan nagyobb volt az Achilles-inak esetében, mint az STG$(p=0,0166), P L-(p=0,0039)$ és TA-graftoknál $(p=0,004)$. Ugyanígy a quadriceps íngraftok is elmaradtak a TA- $(p=0,00226)$ vagy a PL-hez képest $(p=0,0006)$. Azaz a quadricepsek és az Achilles-inak sokkal kevésbé voltak ellenállóak a szakítási erőkkel szemben. A szakadási nyúlás esetén hasonló tendenciákat figyelhettünk meg: az Achilles-inakat a PL- $(p=0,00045)$ és a TA( $p=0,00066)$ graftokhoz viszonyítva; továbbá a quadricepset szintúgy a PL- $(p=0,00045)$ és a TA( $p=0,00066)$ mintáinkkal összevetve a különbség szignifikáns volt.

A mért eredményeinket mediánban reprezentáltuk a hozzá tartozó interkvartilis tartománnyal és ahol szignifikáns volt a különbség a csoportok között, ott nyomtatott nagybetűvel jeleztük (4-7. ábra).

A gammasugárzás hatásait vizsgálva az inakon megállapítható volt, hogy a legrosszabb eredményeket összességében a quadriceps graftok esetén tapasztaltunk. A rugalmassági modulus értékeiben szignifikáns csökkenés mutatkozott a B- és C-csoport összehasonlításakor $(p=0,048)$. A sugárdózis növelésével a csoportok között szintén szignifikáns differencia mutatkozott, mind a nyúlás maximális feszültségnél ( $A$ csoport vs. $C$ csoport: $p=0,0021$, B csoport vs. C csoport: $p=0,015)$, mind a szakadási nyúlásnál (A csoport vs. C csoport: $p=0,0108, B$ csoport vs. C csoport: $p=0,0048)$. A maximális feszültségre nem volt szignifikáns hatással a vizsgált dózisú gammabesugárzás. 


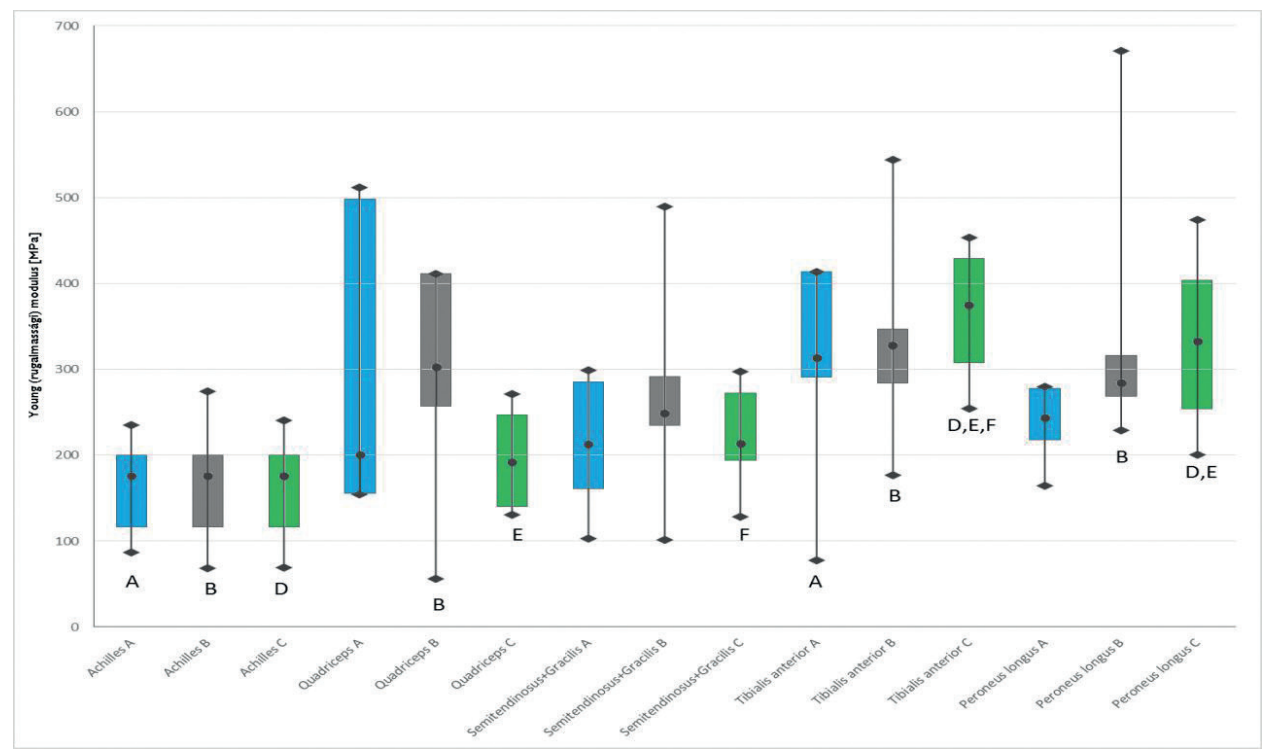

4. ábra

A kontroll-, a baktericid dózissal besugarazott és a virucid dózisú sugárzással kezelt csoportokban mért Young modulus értékek mediánjai a hozzájuk tartozó interkvartilis tartománnyal, amelyeket színes boxokkal ábrázoltunk. Vékony vonalak kötik össze a csoportokban mért minimális és maximális értékeket, nyomtatott nagy betükkel pedig az adott csoportok közötti szignifikáns különbségeket jeleztük.

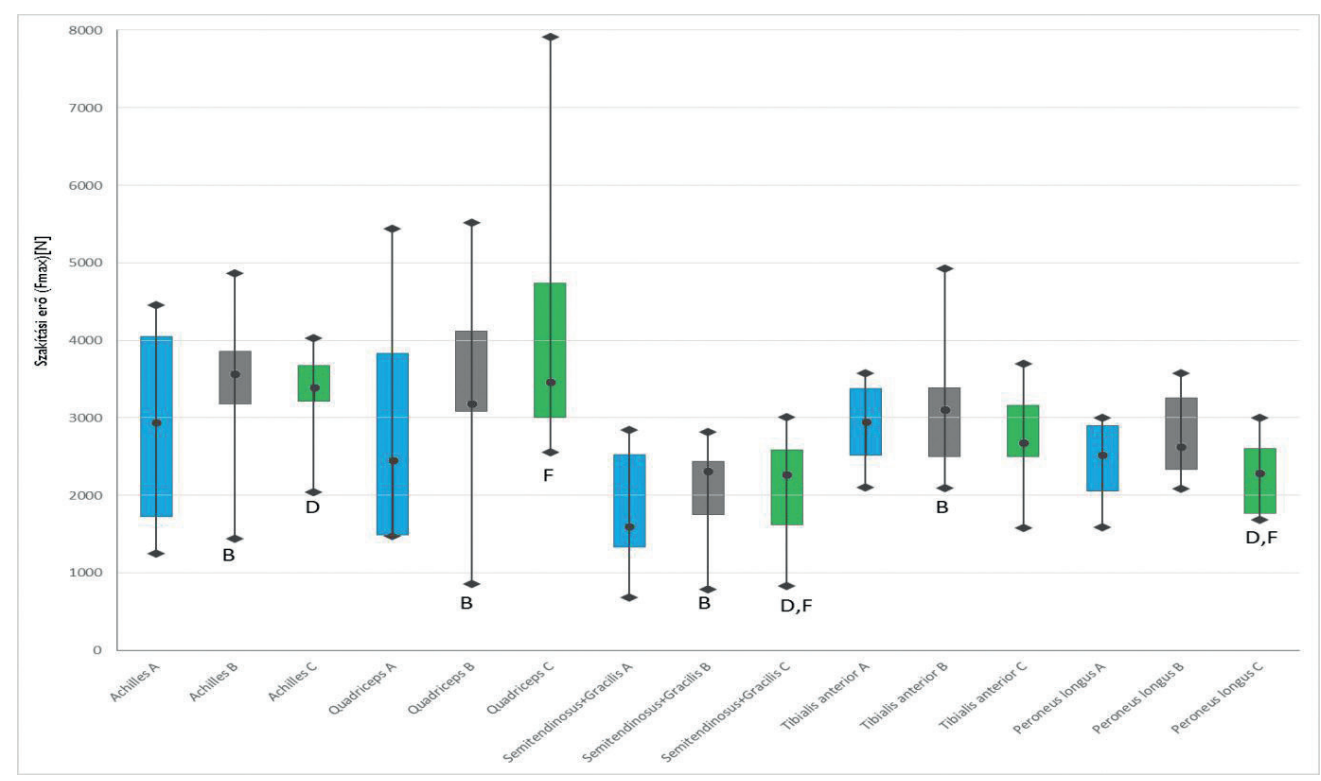

5. ábra

A kontroll-, a baktericid dózissal besugarazott és a virucid dózisú sugárzással kezelt csoportokban mért szakítási erö értékek mediánjai a hozzájuk tartozó interkvartilis tartománnyal, amelyeket színes boxokkal ábrázoltunk. Vékony vonalak kötik össze a csoportokban mért minimális és maximális értékeket, nyomtatott nagy betükkel pedig az adott csoportok közötti szignifikáns különbségeket jeleztük. 


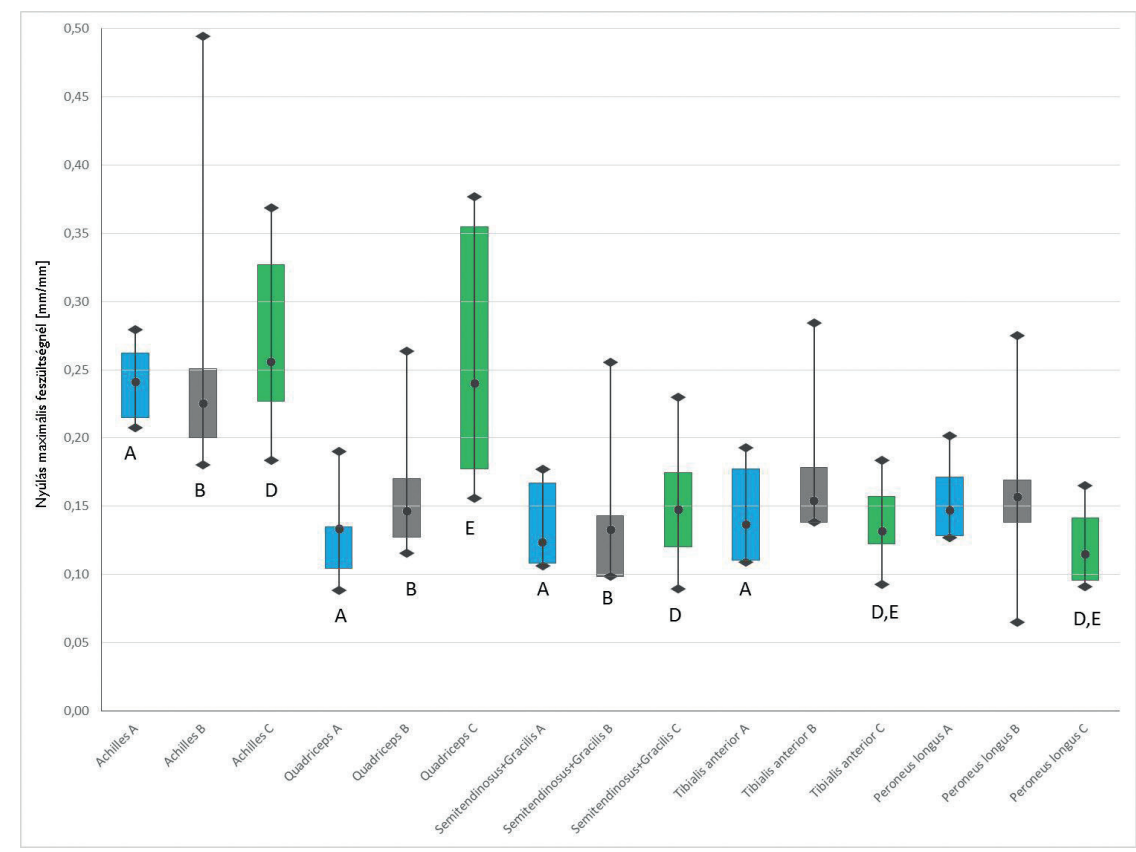

6. ábra

A kontroll-, a baktericid dózissal besugarazott és a virucid dózisú sugárzással kezelt csoportokban mért nyúlás maximális feszültségnél értékek mediánjai a hozzájuk tartozó interkvartilis tartománnyal, amelyeket színes boxokkal ábrázoltunk. Vékony vonalak kötik össze a csoportokban mért minimális és maximális értékeket, nyomtatott nagy betűkkel pedig az adott csoportok közötti szignifikáns különbségeket jeleztük.

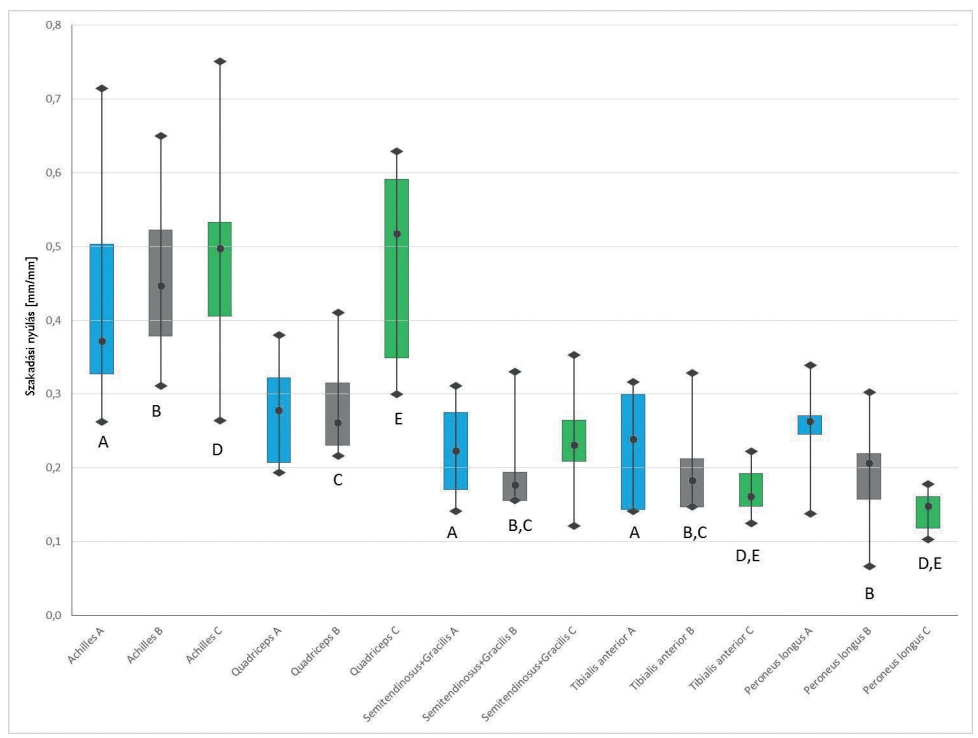

7. ábra

A kontroll-, a baktericid dózissal besugarazott és a virucid dózisú sugárzással kezelt csoportokban mért szakadási nyúlás értékek mediánjai a hozzájuk tartozó interkvartilis tartománnyal, amelyeket színes boxokkal ábrázoltunk. Vékony vonalak kötik össze a csoportokban mért minimális és maximális értékeket, nyomtatott nagy betűkkel pedig az adott csoportok közötti szignifikáns különbségeket jeleztük. 


\section{KÖVETKEZTETÉSEK}

A mai napig is uralkodó autológ irányzat mellett az elmúlt 10-15 évben egyre nagyobb teret kezdett el nyerni az allografttal végzett elülső keresztszalag-pótlás opciója, amely számos kedvező tulajdonsággal rendelkezik $(11,30)$.

A legnagyobb probléma, amely felmerül egy ilyen típusú „idegen szövet” használatakor, a potenciál a betegségek átvitelére, továbbá egy esetleges autoimmun reakció és az így kialakuló kilökődés veszélye. A további nehézségek között említendő a graft nyerésének és tárolásának kérdései.

Ezeket figyelembe véve célunk egy olyan eljárás kifejlesztése volt, amely csökkenti a gammasugárzás és a fagyasztás káros hatásait az ínmintákon. A későbbiekben ez lehet az első lépése egy "off the shelf" típusú termék kifejlesztésének.

a) A szakításos méréseinkhez használt befogófej kifejlesztésekor nyert tapasztalataink

Méréseink megvalósításához az első lépés volt a biomechanikai tesztekhez használandó, alkalmas befogófej kifejlesztése. Vizsgálataink során 6-féle különböző rögzítési technikát teszteltünk. A Shi-féle befogófej, amelyet fagyasztással kombináltunk, volt az egyetlen rögzítési metódus, amely elegendő fixálást biztosított terheléses méréseink alatt (8). Korábban már egyes szerzők közölték, hogy a minták csontos végeit polymetil-metakrilátba (PMMA) ágyazva alkalmas rögzítési felszínt érhetünk el (23). Hibrid típusú graftoknál, ahol az egyik vég csontos, a másik pedig lágyrész - mint például az Achilles-ín - a befogófejeket nitrogénoxiddal hűtve biztosíthatjuk a lágyrészvég rögzítését.

Ezekhez a rögzítési metódusokhoz azonban túl hosszú preparálási idő és hozzávaló anyagigény is jelentős egy nagy esetszámú vizsgálat kapcsán. Esetünkben - a betanulási periódust leszámítva - a graft rögzítése a befogófejbe és a fagyasztás átlagosan nem tartott tovább 8 percnél. Nagy figyelmet kell fordítani a befogófej hőmérsékletére, ugyanis ha a graftok a befogófejek között fagyossá válnak, akkor a stressztűrő képességük lecsökken, megváltozik a rugalmasságuk, és ez az ín váratlan és idő előtti szakadásához vezet. Az átlagos hútési idő bizonyos becslések szerint 3-5 perc
(16). Gyakorlatunkban 3 perces fagyasztási időt használtunk. A befogófej közvetlen környezetében az inakban fagyás nem alakult ki, továbbá a felületen lévő sóoldat is cseppfolyós maradt, így elmondható, hogy a vizsgálandó graftokban fagyási jelet nem észleltünk.

További lehetséges alternatíva a termoelektromos hútés. Ilyen esetben az alacsony hőmérsékletet elektromosan érjük el. A hútés első szakasza addig tart, míg a graft hőmérséklete el nem éri a 0 Celsius fokot, ezt követően egy lassabb fagyasztási fázis következik. Ennek a módszernek a teljes kivitelezési ideje vizsgált mintánként mintegy 45-85 perc, ebből következően nagyszámú minta esetén az időfaktort tekintve nem egy versenyképes opció.

Az irodalomban más szerzők által említett egyéb befogófejekkel elért szakítási erők $1300 \pm 229 \mathrm{~N}$-tól 2549 $\pm 434 \mathrm{~N}$-ig terjednek (25). Vizsgálataink során a szakítási erők átlaga $2198 \pm 771 \mathrm{~N}$, a szakadási erő maximuma pedig 3298,5 N volt. Ezek a számok az előbb említettekkel összhangban voltak. Ellentétben más tanulmányokkal - ahol intakt inakkal dolgoztak - mi az LCA pótláshoz szükséges méretet teszteltük, ezért az Achilles-, a quadriceps- (és korábban a patella-) inaknak csak a középső harmadát használtuk. Hoburg és munkatársai végeztek méréseket a patella-ín középső harmadával, átlagosan 1630,5 $\pm 331 \mathrm{~N}$ szakítási erőt elérve (11). Ez megfelel az általunk mért értékeknek. Vizsgálatunk során ugyanis arra törekedtünk, hogy hasonló átmérőjű graftokkal dolgozzunk, mint elülső keresztszalag-rekonstrukciós mútéteknél.

Mint mindennek, a Shi-féle módosított befogónak is vannak hátrányos tulajdonságai. Shi és munkatársai eredetileg szarvasmarhák Achilles-inait használták, amelynek keresztmetszete közel azonos, mint a humán Achillesé. Ezáltal keresztmetszetük 2-3-szor nagyobb, mint az általunk vizsgált graftoké. A nagyobb szélesség nagyobb érintkezési felületet is jelent, így ez nagyobb súrlódási erőt eredményez, amely csökkenti a minták esélyét a befogófejből való kicsúszásra. Gyakorlatunkban olyan graftátmérővel dolgoztunk, amely megfelel az elülső keresztszalagot pótló mútéteknél használtakéval. Ez az oka annak, hogy méréseink során a vékonyabb íngraftok kicsúsztak a befogófejből. 
A másik sarkalatos kérdés az inak hossza volt. Azt állapítottuk meg, hogy az ínmintáinknak minimum $80 \mathrm{~mm}$ hosszúaknak kell lenniük, máskülönben kicsúsznak a rögzítő berendezésből. Ennek oka ugyanaz, mint amit az előbb részleteztünk. A befogófej polietilén pofájának a hossza $37 \mathrm{~mm}$, a két vég miatt ez a távolság $74 \mathrm{~mm}$, és ehhez még hozzáadódik egy minimálisan is $5 \mathrm{~mm}$ hosszú, befogófejek közti távolság. Ha az inak hossza nem éri el a $80 \mathrm{~mm}$-t, akkor az érintkező felületek nem elég nagyok, ezáltal a súrlódási erő csökken, így okozva a graftok szakadás helyetti kicsúszását. Végül a Shi-féle befogónak nagy hátránya, hogy nem képes a csontos végeket befogni, mivel azok jelentősen destruálják a polietilén betéteket.

Összefoglalásképpen elmondhatjuk, hogy az általunk kifejlesztett módosított befogó egy jól működő módszer volt, nagy erők esetén is jól fixálta a mintákat. Azaz, sikerült megtalálnunk a statikus és dinamikus biomechanikai mérésekhez egyaránt alkalmas lágyrészgraftok rögzítésére szolgáló befogófejet. Ezzel saját munkánkon túl más, hasonló kutatási modellekkel való összehasonlításra alkalmas metodikát hoztunk létre.

\section{b) Fagyasztás és gammabesugárzás ínallograftokra gyakorolt hatásainak konklú- ziói}

Az utóbbi években egyre több az elülső keresztszalagpótló mútétek száma, emellett az allograftok használata is növekszik. Az allograftoknál alapvető igény, hogy olyan sterilizálási eljárást használjunk, amely az ín biomechanikai integritását a legjobban megőrzi (15). Kutatásunk során a gammasugárzás biomechanikai hatását vizsgáltuk 5 különböző az elülső keresztszalag pótlására potenciálisan alkalmas - ínallograftnál.

Eredményeink azt mutatták, hogy a különböző típusú allograftoknak eltérő iniciális biomechanikai tulajdonságai vannak. Véleményünk szerint a legfontosabb paraméter a Young-modulus, amely leírja, hogy a minta milyen rugalmassággal válaszol a terhelésre. Alacsony dózisú besugárzáskor a Young modulusok vonatkozásában a csoportokat összehasonlítva a TA- és PL-inak jobban teljesítettek, mint az Achilles-csoport. Magasabb dózis esetén az Achilles-, az STG- és a quadriceps inak rugalmassági modulusa maradt el a PL- és TA-íngraftokhoz képest. Conrad és munkatársai tanulmányukban az Achilles-inakat vizsgálva szignifikáns Young-modulus-csökkenést észleltek 15/25 kGy gammabesugárzáskor: 292 $\mathrm{MPa}, 154 \mathrm{MPa}$ és $129 \mathrm{MPa}$ (4). A megkétszerezett TA- és PL-inak a Young-modulus, a nyúlás maximális feszültségnél és a szakadási nyúlásnál is azonosan vagy jobban teljesítettek az összes többi általunk vizsgált, a keresztszalag pótlására alkalmas ínallograftnál. Megállapítható volt, hogy az Achilles-inaknak szerényebb az ellenállási képessége, mint a többi ínnak. Hasonló eredményeket közölt Almqvist (1) és Pearsell is (23). Kutatócsoportunk mérései során megállapítottuk, hogy a TA-graft biomechanikai tulajdonságai jobbak, mint a BPTB-graftoké (9). Ráadásul vizsgálataink során a graftokat idősebb donorokból nyertük, így elképzelhető, hogy a fiatalabb életkorú donáció még előnyösebb biomechanikai tulajdonságokat hordozhat magában. Korábban az irodalomban már közölték $(1,23)$, hogy a nagyobb - és egyes tanulmányok szerint (15) a kisebb - dózisú besugárzás is rontja a minták biomechanikai tulajdonságait.

A szakítási erők, amelyeket vizsgálataink során mértünk, korreláltak a nemzetközi irodalomban mértekkel (1, 4, 8, 23). Mindazonáltal tudva a tényt, hogy egy graft szakítási ereje jelentősen függ a keresztmetszetétől (nagyobb átmérőhöz magasabb szakítási erő szükséges), ezért ezen paraméter statisztikai megítélhetősége kérdéses. A mediánértékek minden minta esetén $2200 \mathrm{~N}$ feletti tartományban voltak, kivételt ez alól csak az A csoport STG-graftjai képeztek.

Sík terepen való sétálás közben a térdízület 303-355 N erővel terhelődik $(14,26)$, amely érték jóval elmarad a szakítási tesztjeink során mindhárom csoportban mértekhez képest. Egy agresszív korai rehabilitáció során hozzávetőlegesen 450-480 N erőbehatás éri a térdet (20). Ez sem közelíti meg az általunk mért maximális feszültségi értékeket. Noyes és Woo mérései alapján egy fiatal felnőtt natív keresztszalagjának elszakításához 2160 N szükséges (21, 29). Más aspektust nézve azonban egy ortopéd sebész számára megfontolandó, hogy egy fonalakkal varrott graft ellenállási tulajdonságai igencsak kérdésesek, ugyanis korábban már közölték, hogy az elülső keresztszalag pótlása 
során használt sebészi fonalak szakítószilárdsága 318-381 N közötti tartományban van (13).

Mabe és munkatársai hasonló nyúlási értékeket mértek maximális feszültségnél, mint munkacsoportunk 9-11 kGy összdózissal besugarazott Achilles- és quadriceps inak esetében: 0,15 $\pm 0,07,0,16 \pm 0,02$ (19). Esetünkben mind az alacsony, mind a magasabb dózisú sugárzás szignifikáns gyengülést okozott a nyúlás maximális feszültségnél és a szakadási nyúlási paraméterekben az Achilles- és a quadriceps graftok csoportjaiban. Ez azt jelentheti, hogy egy nagyobb dózisú gammasugárzás ezen inak ellenállását csökkenti a nyújtó erőkkel szemben, ezáltal csökken a képességük az eredeti hosszra való visszarendeződésre. Conrad és munkatársai is szignifikáns $(p=0,0061)$ különbséget írtak le a kontroll- és a besugarazott - 15-25 kGy - csoportok között, a nyúlási értékeket vizsgálva (4). Ez okozhat egy fokozott laxitást allografttal végzett elülső keresztszalagrekonstrukció után (7).

Az előbbiek alapján megállapítható, hogy a szakítási erők, a rugalmassági modulus és a maximális feszültségnél fellépő nyúlás kritikus szereppel bírnak egy ízület szalagjaiban fellépő megnyúlás potenciáljában. TA-ín esetében nem volt szignifikáns különbség a csoportok között, a besugarazott minták hasonló elaszticitási tulajdonsággal rendelkeztek, mint a kontrollcsoport. Hasonló mért értékekkel rendelkezünk a PL-inak esetében, azzal a kitétellel, hogy a 42 kGy dózisú besugárzás szignifikánsan növelte a szakadási nyúlást a kontrollhoz képest. A mért rugalmassági tulajdonságok TA-ín esetében szintén nem változtak szignifikánsan. Samsell is közölte, hogy alacsony dózisú besugárzás nem rontja a TA-allograftok biomechanikai tulajdonságait (24).

Terminális besugárzás szükséges az allograftok sterilitásának eléréséhez (csíraszám $\left.\leq 10^{-6}\right)$, amely feltétel ekvivalens az orvosi eszközök beültetésének kritériumaival. Alacsony dózisú besugárzás (10-15 kGy) szigorú donorszűréssel és megfelelő feldolgozási eljárással kombinálva - amely olyan baktericid procedúrát használ, ami nem befolyásolja szignifikánsan az iniciális biomechanikai tulajdonságokat - szintén sikeres út lehet a klinikai alkalmazás felé (24).

A kis- és nagydózisú gammabesugárzás a quadriceps és Achilles-íngraftok biomechanikai tulajdonságaira volt a legrosszabb hatással. A sugárzás az STG- és PL-inakat kevésbé károsította, de a kezdeti biomechanikai tulajdonságaik kedvezőtlenebbek, mint a tibialis anterior inaké. További tény, hogy a hamstring inas pótlás során - amely manapság az egyik legnépszerúbb LCA-pótló eljárás - az inakat 4 rétegüre hajtjuk, és ezeket fonalas öltésekkel egyesítjük, esetlegesen a gracilis inat is hozzávéve. A TA- és PL-ín opciójakor csak egy ínköteg használata is elégséges.

A graftválasztást illetően a 3 csoportban mért eredményeink alapján elmondható, hogy:

- Amennyiben egy sebész friss-fagyasztott allografttal szeretne szalagpótlást végezni, úgy az Achilles-ín kivételével a másik 4 általunk vizsgált graft ajánlható. Ebben az esetben az alapos donorszúrés elengedhetetlen feltétel a fertőzéses megbetegedések átvitelének csökkentésére.

- Ha baktericid dózissal kezelt graftokra fordítjuk a figyelmünket, a TA-, PL- és a STG inak javasolhatóak implantálásra. A virális és egyéb potenciálisan fertőző ágensek elkerülése miatt itt is nagy jelentősége van az alapos donorszúrésnek.

- Amennyiben a legmagasabb szintű mikrobiológiai biztonságra törekszünk, azaz virucid dózisú gammabesugárzással kezeljük a mintáinkat, abban az esetben a TA-ínallograft használata a legmegfelelőbb választás.

Ezért egy a későbbiekben forgalmazásra potenciálisan alkalmas humán ínallograft alapú "off the shelf" terméknél a tibialis anterior inat ajánljuk elsődleges választásként. 


\section{IRODALOM}

1. Almqvist K. F., Jan H., Vercruysse C., Verbeeck R., Verdonk R.: The tibialis tendon as a valuable anterior cruciate ligament allograft substitute: biomechanical properties. Knee Surg. Sports Traumatol. Arthrosc. 2007. 15. (11): 1326-1330. https://doi.org/10.1007/s00167-007-0396-7

2. Cameron M. L., Mizung Y., Cosgarea A. J.: Diagnosing and managing anterior cruciate ligament injuries. J. Musculoskelet. Med. 2000. 17: 47-53.

3. Cohen S. B., Sekiya J. K.: Allograft safety in anterior cruciate ligament reconstruction. Clin. Sports Med. 2007. 26. (4): 597605. https://doi.org/10.1016/j.csm.2007.06.003

4. Conrad B. P., Rappé M., Horodyski M., Farmer K. W., Indelicato P. A.: The effect of sterilization on mechanical properties of soft tissue allografts. Cell Tissue Bank, 2013. 14. (3): 359-366. https://doi.org/10.1007/s10561-012-9340-2

5. Cooper J. A.: Design, optimization and in vivo evaluation of a tissue-engineered anterior cruciate ligament replacement. Ph.D. thesis. Drexel University Press, Philadelphia, 2002.

6. Curl W. W., Krome J., Gordon E. S., Rushing J., Smith B. P., Poehling G. G.: Cartilage injuries: A review of 31,516 knee arthroscopies. Arthroscopy, 1997. 13. (4): 456-460. https://doi.org/10.1016/S0749-8063(97)90124-9

7. Cvetanovich G. L., Mascarenhas R., Saccomanno M. F.: Hamstring autograft versus soft-tissue allograft in anterior cruciate ligament reconstruction: a systematic review and meta-analysis of randomized controlled trials. Arthroscopy, 2014.30. (12): 1616-1624. https://doi.org/10.1016/i.arthro.2014.05.040

8. Hangody Gy., Pánics G., Szebényi G., Kiss R., Hangody L., Pap K.: Pitfalls during biomechanical testing - Evaluation of different fixation methods for measuring tendons endurance properties. Physiol. Int. 2016. 103. (1): 86-93. https://doi.org/10.1556/036.103.2016.1.8

9. Hangody Gy., Szebényi G., Abonyi B., Kiss R., Hangody L., Pap K.: Has the different dose of gamma irradiation the same effect on five different types of tendon allografts? A biomechanical study. Int. Orthop. 2017. 41. (2): $357-365$. https://doi.org/10.1007/s00264-016-3336-7

10. Hangody L.: Current concept of ACL reconstruction and revision - 2007. International Sportsmedicine Symposium of the Turkish Arthroscopic and Sportsmedicine Associations, 25th-28th April 2007, Antalya, Turkey.

11. Hoburg A. T., Keshlaf S., Schmidt T., Smith M., Gohs U., Perka C., Pruss A., Scheffler S.: Effect of electron beam irradiation on biomechanical properties of patellar tendon allografts in anterior cruciate ligament reconstruction. Am. J. Sports Med. 2010. 38. (6): 1134-1140. https://doi.org/10.1177/0363546509361161

12. Hoburg A., Keshalf S., Schmidt T., Smith M., Gohs U., Perka C., Pruss A., Scheffler S.: High-dose electron beam sterilization of soft tissue grafts maintains significantly improved biomechanical properties compared to standard gamma treatment. Cell Tissue Bank, 2015. 16. (2): 219-226. https://doi.org/10.1007/s10561-014-9461-x

13. Hong C. K., Lin C. L., Chang C. H., Jou I. M., Su W. R.: Effect of the number of suture throws on the biomechanical characteristics of the suture-tendon construct. Arthroscopy, 2014. 30. (12): 1609-1615. https://doi.org/10.1016/i.arthro.2014.06.029

14. Jones D. B., Huddleston P. M., Zobitz M. E., Stuart M. J.: Mechanical properties of patellar tendon allografts subjected to chemical sterilization. Arthroscopy, 2007. 23. (4): 400-404. https://doi.org/10.1016/i.arthro.2006.11.031

15. Jung H. J., Vangipuram G., Fisher M. B., Yang G., Hsu S., Woo S. L.: The effects of multiple freeze-thaw cycles on the biomechanical properties of the human bone-patellar tendon-bone allograft. J Orthop Res. 2011. 29. (8): 1193-1198. https://doi.org/10.1002/jor.21373

16. Kiss M. O., Hagemaister N., Levasseur A., Fernandes J., Lussier B., Petit Y.: A low-cost thermoelectrically cooled tissue clamp for in vitro cyclic loading and load-to-failure testing of muscles and tendons. Med. Eng. Phys. 2009. 31. (9): 1182-1186. https://doi.org/10.1016/i.medengphy.2009.06.008

17. Kustos T., Balint L., Than P., Bardos T.: Comparative study of autograft or allograft in primary anterior cruciate ligament reconstruction. Int. Orthop. 2004. 28. (5): 290-293. https://doi.org/10.1007/s00264-004-0568-8

18. Lawhorn K. W., Howell S. M.: Scientific justification and technique for anterior cruciate ligament reconstruction using autogenous and allogeneic soft-tissue grafts. Orthop. Clin. North Am. 2003. 34. (1): 19-30. https://doi.org/10.1016/50030-5898(02)00029-9

19. Mabe I., Hunter S.: Quadriceps tendon allografts as an alternative to Achilles tendon allograft: a biomechanical comparison. Cell Tissue Bank, 2014. 15. (4): 523-529. https://doi.org/10.1007/s10561-014-9421-5

20. Nagura T., Matsumoto H., Kiriyama Y., Chaudhari A., Andriacchi T. P.: Tibiofemoral joint contact force in deep knee flexion and its consideration in knee osteoarhrosis and joint replacement. J. Appl. Biomech. 2006. 22. (4): $305-313$. https://doi.org/10.1123/jab.22.4.305

21. Noyes F. R., Butler D. L., Grood E. S., Zernicke R. F., Hefzy M. S.: Biomechanical analysis of human ligament grafts used in knee-ligament repairs and reconstructions. J. Bone Joint Surg. Am. 1984. 66. (3): $344-352$. https://doi.org/10.2106/00004623-198466030-00005

22. Nyland J., Caborn D. N., Rothbauer J., Kocabey Y., Couch J.: Two-year outcomes following ACL reconstruction with allograft tibialis anterior tendons: a retrospective study. Knee Surg. Sports Traumatol. Arthrosc. 2003. 11. (4): 212-218. https://doi.org/10.1007/s00167-003-0371-x

23. Pearsall A. W., Hollis M. J., Russel G. V. Jr., Scheer Z.: A biomechanical comparison of three lower extremity tendons for ligamentous reconstruction about the knee. Arthroscopy, 2003. 19. (10): 1091-1096. https://doi.org/10.1016/i.arthro.2003.10.015 
24. Samsell B. J., Moore A M.: Use of controlled low dose gamma irradiation to sterilize allograft tendons for ACL reconstruction: biomechanical and clinical perspectives. Cell Tissue Bank, 2012. 13. (2): $217-223$. https://doi.org/10.1007/s10561-011-9251-7

25. Scheffler S. U., Scherler J., Pruss A., von Versen R., Weiler A.: Biomechanical comparison of human bone-patellar tendon-bone grafts after sterilization with peracetic acid ethanol. Cell Tissue Bank, 2005. 6. (2): $109-115$. https://doi.org/10.1007/s10561-004-6403-z

26. Shelburne K. B., Torry M. R., Pandy M. G.: Muscle, ligament and joint-contact forces at the knee during walking. Med. Sci. Sports Exerc. 2005. 37. (11): 1948-1956. https://doi.org/10.1249/01.mss.0000180404.86078.ff

27. Shi D. F., Wang D. M., Wang C. T., Liu A.: A novel, inexpensive and easy to use tendon clamp for in vitro biomechanical testing. Med. Eng. Phys. 2012. 34. (4): 516-520. https://doi.org/10.1016/i.medengphy.2011.11.019

28. Siebold R., Buelow J. U., Bös L., Ellermann A.: Primary ACL reconstruction with fresh-frozen patellar versus Achilles tendon allografts. Arch. Orthop. Trauma Surg. 2003. 123. (4): 180-185. https://doi.org/10.1007/s00402-003-0476-1

29. Woo S., Hollis M., Adams D., Lyon R., Takai S.: Tensile properties of the human femur-anterior cruciate ligament - tibia complex. Am. J. Sports Med. 1991. 19. (3): 217-225. https://doi.org/10.1177/036354659101900303

30. Wren T. A., Yerby S. A., Beaupré G. S., Carter D. R.: Mechanical properties of the human Achilles tendon. Clin. Biomech. 2001. 16. (3): 245-251. https://doi.org/10.1016/S0268-0033(00)00089-9

\section{Dr. Hangody György Márk}

Uzsoki Utcai Kórház, Ortopéd-Traumatológiai Osztály

1145 Budapest, Uzsoki u. 29. 
